\title{
The Impact of Human Resource Management Policies on Business and Marketing Strategy Implementation within the Marketing Organization
}

\section{A. VARADARAJ', M. PRASANNA MOHAN RAJ', S. $A N A N T H^{3}$}

\begin{abstract}
During the last three decades, significant research has been undertaken on the characteristics and relationships of the marketing organization with the implementation of strategies. These are the structure, culture, processes, and influence and leadership characteristics of the marketing institution. However, there has been little attention given to the human resources management policies of the marketing staff. These policies are one of the strongest sensations of people and organizations, when properly implemented, to conduct themselves correctly. In this study, we show that mid-level marketer implementation of HR policies differ substantially in the type of marketing strategy adopted by the companies. Companies with aligned enterprise and marketing strategies have achieved considerably stronger performance than companies with unequalled business and marketing strategies.
\end{abstract}

Keywords: Marketing strategy, management of resources, implementation of marketing strategies, types of strategy, performance

JEL Code: $M 10$

\section{Introduction}

The fast marketing, technological or strategic changes continue to make the marketing organization's study important and pertinent since at least 1957.

\footnotetext{
${ }^{1}$ Dr. A.Varadaraj is an Professor, Alliance School of Business Bengaluru, India. Email: avraj28@gmail.com. https://orcid.org/0000-0002-0482-7369

${ }^{2}$ Dr. M. Prasanna Mohan Raj is an Associate Professor, Alliance School of Business Bengaluru, India

${ }^{3}$ Dr. Ananth. S is an Assistant Professor, Alliance School of Business Bengaluru, India
} 
The marketing organization's characteristics were specifically studied (Workman Jr et al., 1998). The study focuses on following: marketing policies (Homburg et al., 2012; Olson, 1994; Olson et al., 1995, 2005; Olson \& Slater, 2002; Vorhies \& Morgan, 2003, 2005), culture, strategy development and implementation development (Deshpandé et al., 1993), for instance: (Atuahene-Gima \& Murray, 2004; Slater et al., 2006, 2007, 2011; Slater \& Narver, 1993; Slater \& Olson, 2000, 2001, 2002). A marketing structure is another important element of the marketing strategy (Jaworski \& Kohli, 1993; Vorhies \& Morgan, 2005). HRM policies for medium-sized marketing managers represent a major but largely unknown corporate and strategic consideration.

To create a competitive advantage, we first study literature related to marketing policy and HRM. We focus on key categorical HR policies affecting marketing function and the functioning of marketing managers. In response, we will discuss the strategic contingency factors that affect the relative importance of this marketing policy for marketers and the implications of variations in corporate performance overall. Our research design and analysis techniques are then described. Our analysis results, its interpretation and its organizational and scholarly implications are covered in the final section of the manuscript.

Ballantyne (2000) identified the potential benefits of integrating HRM thinking in the marketing sector in the context of an internal marketing concept for the banking sector. Piercy, (1998); Porter, (1980) speculated on the huge advantages of improved HR and marketing collaboration. Four various mechanisms have been identified:

- Customer training redirection,

- Enhanced employee ownership for meetings,

- Customer tracking and employee satisfaction, and

- Customer satisfaction remediation and training measures.

Chimhanzi (2004) has developed and tried a conceptual model with effective HR and marketing ties focusing on marketing strategy's history. Her thesis is that successful strategic implementation is based on everyday activities at all company levels, including marketing. Factors like poor education and poor motivation lead to poor marketing performance. This can be done via isolated HR systems (training, rewards, remuneration, development, assessment). 
Similarly, if marketing strategies and plans are developed isolatedly, HR may not understand the marketing function. It is assumed that the effectiveness of the marketing strategy is determined by the extent of the link between HR and marketing and the frequency and non-conflict between the two tasks, written communication and interpersonal communication. Unfortunately, the only positive relationship with the defined results variable was interpersonal communication and the lack of conflict.

Although these studies supported the concept of improving HRM's marketing functions, they are broad guidelines. As a group, there are no reductions in the levels of the specific HRM policies. Policies on staff resources "consist of functions and activities necessary for the effective management of the company's human resources. The main aims of these activities have traditionally been to attract, retain and motivate employees." In this study, we examine middle management policies for selection, education, assessment and compensation, so that those relating to higher business overall results are identified (if not conclusively causal).

Barney (1991) and Barney \& Wright (1998) were introducing the first strict concept for competitive advantages "where a company implements a value creation strategy that is not being implemented simultaneously by existing or potential competitors". The competitive advantage, therefore, demands a valuable and rare resource. However, copying the valued and rare value of a source is not easier for competitors. It must also be difficult to imitate and not replace a resource for a sustainable competitive advantage (Balkin \& Gomez-Mejia, 1990). According to Barney (1991), first resources include every asset that allows the company to devise and implement strategies including all organizational processes, corporate characteristics, information, knowledge, etc. Wright et al (1994) pointed out the company's possibility to provide a competitive source of benefits "including all of the knowledge, experience, expertise and commitment of its employees." From this study, the main question is how organizational processes for managing human resources facilitate the development of a strategy and its implementation? "People and how we handle them become increasingly important because many more competitive success sources are less strong than they were," argued (Pfeffer, 1992; Pfeffer \& Salancik, 2003; Wright et al., 1994, 2001). "The organization, its employees and how they operate 
remain as a crucial, differentiating factor" he continues to argue. Many investigations have been published that link the resource-based approach to the function of human resources.

Selection: "The most obvious way companies improve their human capital stocks is through the individuals they hire". Snell \& Dean Jr. (1992) suggest that businesses with more complex processes need specialized personnel to find the most skilled candidates and recruit them who need more time and resources on the company's side. Higher productivity levels reduce this additional cost.

Training: Companies invest in education when improved education promises a higher level of productivity than direct training costs (Miles et al., 1978; Snell \& Dean Jr, 1992). In addition, investments are more likely in training companies that produce complex goods or services and/or companies that produce rapidly developing products or services.

Appraisal: The evaluations of performance have two objectives: administration (for example, which promotes, ends and increases) and development (Hofstede, 1978; Huber \& Power, 1985) (e.g. to what extent feedback and the needs for training are taken into account). Becker (1962) says that employee development is useful if enhanced expertise is in line with the commitment to generate extra revenue or to increase productivity above training costs. This concept means, therefore, that if the importance or the impact of decision-making by these staff is potentially increasing, the costs of a thorough assessment by marketing staff are financially reasonable.

Compensation: Compensation systems are designed to recompense past conduct and have noted the multidimensional compensation design (Balkin \& Gomez-Mejia, 1990; Barney, 1991; Becker, 1962). Three broad categories have been identified: pay strategy, positioning on the market and pay policy. In the wage strategies, the wage mix, its benefits and stimulus are of relative importance. Positioning in the market refers to an above or below the average industry level of payment of certain companies. The pay policy decisions take into account the administrative and procedural criteria of the company in compensating employees (J. B. Barney \& Wright, 1998; Wright et al., 2001). Every pay policy measure they include in their study is not explained descriptively (Balkin \& Gomez-Mejia, 1990). However, we can infer its significance from the surveys they created for each one. In this study, we have included the following salary policies: 
- Risk-sharing (marketing employee income partly depends on the achievement of departmental performance goals),

- Equity Internal (comparable pay across various marketing departments)

- Level Pay

- Pay based on employment (Employees are only paid for educational and senior positions based on employment functions)

- Payment Duration (recognize that long-term outcomes are more important than short-term ones, that projects can span several years, and that long-term connections with key customers are important).

Figure 1. Conceptual Models

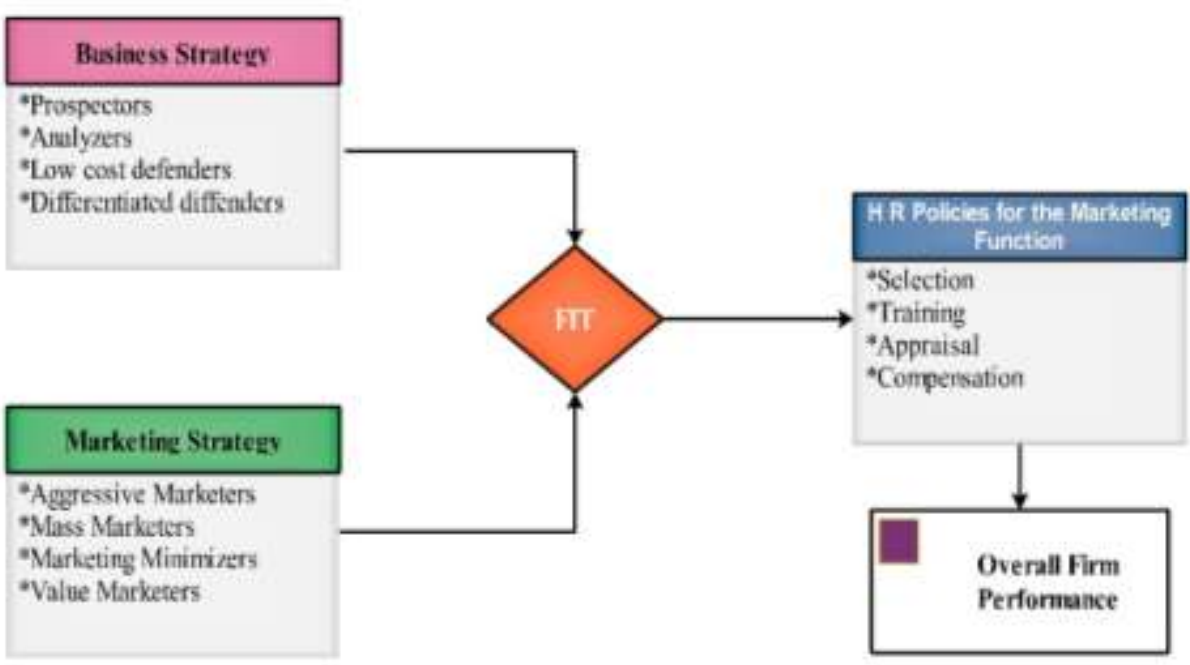

Source: Elaborated by the author

\section{Contingency model}

Figure 1 shows the theses behind this study's HR marketing policy to vary with applications governed by a general business strategy and that comply with the business strategy adopted in the marketing strategy. This corresponds to the observation of Porter (1980), "Strategic fit among many activities is fundamental not only to competitive advantage but also to the 
sustainability of that advantage. It is harder for a rival to match an array of interlocked activities than it is merely to imitate a particular sales-force approach, match a process technology, or replicate a set of product features."

\subsection{Business strategy}

It focuses on companies in the industry or market competitiveness. Varadarajan \& Clark, (1994) and Walker Jr \& Ruekert (1987) have developed the two main business strategy frameworks to address the desired rate of change on the product's market (Hambrick, 2003). The study was based on Ruekert \& Walker Jr, (1987a) findings, which suggested combining the typologies as well as the Slater et al., (2007) studies, with several studies to validate the hybrid business strategy typologies including Olson, (1994); Olson et al., (1995), (2005); Olson \& Slater, (2002); Slater et al., (2007). These covers: prospectors, analyzers, low-cost advocates (rapid second-hand drivers to take advantage of market changes to improve features and services created by market prospectors) (they try to sell out part of the total amount). In this study, we consider (those who attempt to seal a portion of the total market by providing a stable set of products or services of superior quality).

\subsection{Marketing strategy}

Whether or not the company is supported by its strategy/section and the targets of a large company are largely dependent on the success of this marketing strategy (Walker Jr \& Ruekert, 1987). The marketing strategy includes a series of integrated decisions and measures that enable a company to meet its marketing objectives and its customers' value requirements (Cravens, 1998; Varadarajan \& Clark, 1994). The marketing strategy focuses on market division and a focused product development strategy and policy strategy (Conant et al., 1990; Huber \& Power, 1985; Hunt \& Morgan, 1995; Kotler \& Turner, 1997; McCarthy et al., 1979).

Slater \& Olson (2001) Empirical marketing strategy consisted of four alternatives. The following are in this section:

- High quality, innovative and aggressive marketers, premium prices, selected distribution strategies, internal marketing force, public investment and promotional marketing functions. 
- Mass marketers: provide a wide variety of products that are largely indifferent and sold at low prices in the intensive marketing system.

- Marketing minimizers: providing the lowest customer services in limited product ranges and innovative and low-price marketing.

- Selective distributors serve value marketers to offer high quality but lower innovative products prices than aggressive, domesticsales-based markets.

Slater \& Olson, (2001) combined business and marketing strategies, showed superior business results (i.e., Fit). The matches have been chosen specifically: marketing aggressors, prospectors, mass analyzers, marketers, cheap advocates, marketing minimizers and leading supporters and value marketers. Although the best combinations are found, companies with a different choice of marketing strategies (e.g., MISFIT, whose marketing strategy has been selected by the mass marketer, minimizer or value marketer) existed for each type of business strategy. They note that they have been optimized (Bund \& Carroll, 1957; Conant et al., 1990; Huselid et al., 1997; Katz \& Kahn, 1978; Matsuno \& Mentzer, 2000; McKee et al., 1989; Olson et al., 2001; Slater \& Narver, 1993; Venkatraman, 1990).

\subsection{Impact of HR policies by business strategy type on the marketing function}

The differences in HR compensation policy were reviewed by Balkin \& Gomez-Mejia, (1990) in the format. Three alternative Corporate Strategies (one product, one dominant produced, another associated product) and (growth vs maintenance). You did important research because they were largely descriptive or were not focused on certain tasks (e.g. marketing, operations).

There are two important ways to build on your studies. We concentrate mostly exclusively on marketing. Secondly, we examine HR marketing policies simultaneously in four alternative business strategies and four alternative marketing policies.

Snell \& Dean Jr, (1992) and Wright et al., (2001) noted that companies mainly invest in their employees using human resources. However, such investments are not uniform in all companies. Such companies are better 
managed varies in human capital investment (Atuahene-Gima \& Murray, 2004; Ballantyne, 2000). Marketing research has shown that the relative importance of marketing at least to some extent differs from that of companies with at least one business strategy base (Child, 1972; Collins \& Payne, 1991; Cravens, 1998; Giannakis \& Harker, 2014).

\subsection{The impact of HR policies on the marketing of corporate strategy (fit versus misfit)}

"Business and snow business performance is achieved through combining particular marketing strategies with the right types of miles and the proper snow," said (46). Therefore, in each HR mentioned above policies issues, we now explore the difference in the type of business strategy.

Table 1. Predicted links between the type of business strategy \& the marketing HR policies

\begin{tabular}{|l|c|c|c|c|}
\hline & Prospectors & Analysers & $\begin{array}{c}\text { Low cost } \\
\text { defenders }\end{array}$ & $\begin{array}{c}\text { Differentiated } \\
\text { defenders }\end{array}$ \\
\hline Selection(importance) & Very high & High & Low & Very high \\
\hline Training(importance) & Very high & High & Low & High \\
\hline $\begin{array}{l}\text { Appraisal (importance) } \\
\text { Compensation }\end{array}$ & Very high & High & Low & High \\
\hline Salaries & Very high & High & Low & Very high \\
\hline Benefits & Very high & High & Low & Very high \\
\hline Incentives & Very high & Very high & Low & Low \\
\hline Compared to competitors & Very high & High & Low & High \\
\hline Shared risk & Very high & High & Low & Moderate \\
\hline Internal consistency & Low & Low & High & High \\
\hline Merit Based pay & Very high & High & Low & Low \\
\hline Job-based pay & Low & Low & High & High \\
\hline Long-term & Very high & High & Low & Moderate \\
\hline
\end{tabular}

Source: Elaborated by the author

The resource theory again underlines that the key to business success is political consideration (for example, prospectors) (i.e., aggressive marketing, 
Mass Marketers, Marketing Minimizers, and Value Marketers). For companies who have a key marketing role in the governing coalition, that seems logical. However, if we predict that the average policy measures for HR will be reduced, this may not apply to low-cost advocates. Raises the question of whether it would make sense for companies that follow this strategy, i.e., marketing minimizers, to assume that relatively low total scales are less than malfunctioning. The logical conclusion is that there should be absolutely zero results (e.g., the search process for new marketing hires is 0 ). This isn't the validity test because new marketing employees are not fully targeted(Conant et al., 1990; McKee et al., 1989; Olson et al., 2001; Slater \& Narver, 1993; Venkatraman, 1990). In certain ways, new employees must be identified and recruited. Although we expect overall results to be relatively low for fit Low-Cost Defender companies, we do not see any reason to expect that the results will be lower than for fit Low-Cost Defender companies. Therefore, we expect the average value for Low-Cost Defender businesses to not be different from and misadjusted, except in the case of Job-based Pay.

\subsection{Selection, training, and appraisal}

Although the selection, training and evaluation activities are very different, they are highly interrelated by their sequence nature. The companies that rely on their marketing functions spend more time, effort, and money choosing new marketing entries than those that depend less on their marketing skills. These companies will also provide extra resources to train marketing personnel in new contracts of marketing. In view of its relative importance to the company's overall success, the management is also committed to evaluating the achievements of the individual marketing staff over the period.

\subsection{Compensation}

Each company must be reimburse with its marketing personnel. Consequently, there is little useful information on the importance of compensation. Rather, the level of implementation of different pay policies is taken into account. As discussed above, these policies are consistent with three subcategories: salary (salary, benefit, incentive), market positions (in comparison with competitors in marketing departments) and pay policies 
(department of risk-sharing, marketing compensation levels), compensation m compensation ( Huber \& Power, 1985; Katz \& Kahn, 1978; Kotler \& Turner, 1997).

Table 2 includes the same HR policy as Table 1. Marketing Policies, However, we are considering these policies incorporate groups under a certain corporate strategy (e.g., Prospectors). In particular, differences in marketing strategy between firms and prospectors which are not enough to compare or apply HR policies (for example, prosecutorial, aggressive markets) are take into account (e.g., Prospectors: Mass Marketers, Marketing Minimizers, Value Marketers) (Hofstede, 1978; Hrebiniak \& Joyce, 1985; Huber \& Power, 1985; Ittner \& Larcker, 1997; Jaworski \& Kohli, 1993; Kotler \& Turner, 1997). Table 2 shows 48 relationships between fit and fat companies across four kinds of business strategy (selection, training, assessment, and nine compensation policies). In selecting, training and evaluating the processes, we expect that fit firms will be more important and emphasise compensation policy in Table 2.

However, given the small value of small businesses, we do not expect a substantial difference between fitness and malfunctioning companies. There are no expectations of the above HR policies (Atuahene-Gima \& Murray, 2004; Bund \& Carroll, 1957).

\subsection{Overall firm performance}

The goals, strategy and market structure of the company should be performance. We follow other marketing strategy researchers' leadership and global performance measures (Slater et al., 2007; Slater \& Olson, 2001; Venkatraman, 1990). We use complete business performance despite the nature of the contextual influences (i.e. level to which the company fulfilled expectations, exceeded major competitors and achieved high management satisfaction). The organisation's overall operations are perceived to have taken into account only the prior dimension of the organization (return on assets, sales and sales), as stated by Ittner \& Larcker (1997). A strong connection between objective performance data and key informant subjective assessments was identified by Hunt \& Morgan,(1995); Morgan et al., (2004); 
Vorhies \& Morgan, (2003) and Yarbrough et al., (2011) to support the validity of key informant data.

Table 2. Differences in the importance and application of HR marketing policies between fit and malfunctioning companies in the business strategy type are given.

\begin{tabular}{|c|l|l|l|l|}
\hline & $\begin{array}{c}\text { Prospecters \& } \\
\text { Aggressive } \\
\text { Marketers }\end{array}$ & $\begin{array}{c}\text { Analysers \& } \\
\text { Mass } \\
\text { Marketers }\end{array}$ & $\begin{array}{c}\text { Low-cost } \\
\text { Defenders \& } \\
\text { Marketing } \\
\text { Minimizers }\end{array}$ & $\begin{array}{c}\text { Differentiated } \\
\text { Defenders \& Value } \\
\text { Marketers }\end{array}$ \\
\hline Selection(importance) & Higher & Higher & Higherence & Higher \\
\hline $\begin{array}{l}\text { Appraining(importance) } \\
\text { compensation }\end{array}$ & Higher & Higher & No difference & Higher \\
\hline Balaries & Higher & Higher & No difference & Higher \\
\hline Incentives & Higher & Higher & No difference & Higher \\
\hline Compared to competitor & Higher & Higher & No difference & Higher \\
\hline Shared nisk & Higher & Higher & No difference & No difference \\
\hline Internal consistency & No difference & No difference & No difference & Higher \\
\hline Ment Based pay & Higher & Higher & No difference & No difference \\
\hline Job-based pay & No differeace & No differeace & Higher & Higher \\
\hline Long-term & Higher & Higher & No difference & No difference \\
\hline
\end{tabular}

Source: Elaborated by the author

\subsection{1. type of corporate strategy (fit versus misfit)}

When the corporate strategy and marketing strategy (Fit) are adequately matches the overall performance of companies should be higher than those that do not comply with their marketing strategies (Misfit)(Yarbrough et al., 2011). Therefore, we predict the following regarding business performance overall:

- Intra-prospective marketers, aggressive markets, value markets; (Misfit).

- Mass marketers (fit) > Aggressive marketers in analyst companies: (Misfit).

- Low-cost advocates can access marketing minimizers $>$ aggressive marketers. 
- Company's defence: fit marketers > mass marketers, aggressive marketers, divided advocates (Misfit).

\subsubsection{Types of corporate strategy (equanimity)}

The idea is that machines provide superior performance in various strategies and that business performance does not all depend on special strategies (Ballantyne, 2000; Rafiq \& Ahmed, 1993). Therefore, equipment means free choices or flexible strategies when organizational developers create high-performance organizations (Child, 1972). As a fundamental component in implementing strategy, the HR marketing policy determines superior performance by the requirements of a particular strategy. Therefore, the concept of equivalence considers that each of the above four fit companies is identical to the high overall results. We, therefore, expect to see no significant differences in overall corporate performance among fitness groups (Atuahene-Gima \& Murray, 2004; Balkin \& Gomez-Mejia, 1990; Bund \& Carroll, 1957; McKee et al., 1989; Miles et al., 1978; Morgan et al., 2004; Olson et al., 1995, 2005; Olson \& Slater, 2002; Pfeffer, 1992).

\section{The study}

Query was drafted to look for information on five particular business unit topics to test these proposals:

1) What is the HR marketing policy important for employee selection, training and evaluation?

2) At which level are the salary strategies: salaries, benefits, incentives, competitive compensation, risk sharing, consistent internal salaries, salaries based on performance, pay based on employment and longterm compensation?

3) What are overarching corporate strategies?

4) What has been adopted overall marketing strategy?

5) What over the past three years has the company (or business unit) achieved?

When the survey was completed, all participants were asked to consider the largest or best-known business unit. We acquired a mailing list of 1250 
marketing managers with at least 500 employees in service and production companies across the country (J. Barney, 1991; James \& Hatten, 1995; Schuler \& MacMillan, 1984; Vorhies \& Morgan, 2003; Wright et al., 2001). As key informants, we have selected senior marketers to know of the marketing personnel's HR policies. We have selected a personal letter with a brief study explanation for the list of 30 names with a survey questionnaire and an email envelope payable. We asked people to evaluate their business and financial performance in the last five years. We promised to be anonymous but received no answers(Corey, 1992; Giannakis \& Harker, 2014; Gresov \& Drazin, 1997).

The questionnaire was subsequently modified. We no longer asked the company or the respondent's division to identify difficult financial details, and we asked the respondent's opinion in the last three years on three general performance questions(Ruekert \& Walker Jr, 1987b; Shortell \& Zajac, 1990; Slater et al., 2007; Slater \& Olson, 2001; Venkatraman, 1990). We included a pre-card with the same overview of performance issues. We asked independent management to provide corporate data access or divided performance data to increase confidence in these subjective responses. For each respondent, the questionnaire and an appendix to the performance of a post-card were ordered. The remaining 1220 new replies were questions received(Gresov \& Drazin, 1997). Questionnaires. The second mail was forwarded to the same addresses four weeks later. We received 256 replies from these two mailings. Sixty-six were deemed to be unusable since the performance of the post-card checks was only partially carried out and was not combined with post-card results or the general results reported in line with the results reported (e.g. $>> \pm 0$ 332) (Piercy, 1998; Rafiq \& Ahmed, 1993; Schuler \& MacMillan, 1984; Slater \& Narver, 1993). This led to 190 questionnaires, which represent a respectable reaction rate of 15.6 per cent. Eleven of them described their business or unit for competitive reactors as a strategy which means that they have not deliberately activated their business or unit(Atuahene-Gima \& Murray, 2004; Balkin \& Gomez-Mejia, 1990; Bund \& Carroll, 1957; Olson et al., 1995; Pfeffer, 1992). These reduced usable responses to 179 , representing a response rate of 14.7 per cent. Finally, there were reimbursed 74 non-substantial envelopes, up to 15.6 per cent, well above minimum management thresholds. Of the remaining 179 corporate- 
level studies, the Vice Presidents, Directors, Chairs, CEOs or others were completed by a total of 159 (89 per cent) Secondary interviewees were 18.5 and an average of 23.3 years(Collins \& Payne, 1991; Vorhies \& Morgan, 2005; Wright et al., 1994; Yarbrough et al., 2011).

\subsection{Description of the measures}

The action was taken on selection, training and evaluation, and this process focused on the benchmarking importance of companies. Compensation measures, by contrast, were taken that took account of eight specific policy actions in three separate HR-compliance dimensions. There are different dimensions: Pay Package design that covers wages, benefits and incentives(Cravens, 1998; Varadarajan \& Clark, 1994; Workman Jr et al., 1998) Positioning of the market including pay for competitors Pay policy options such as common risks, domestic pay consistency, performance pay, employment and long-term salary.

The Likert scales of five points were very unobtrusive 1= very strongly agreed on the relevant HR policies or adoption measures, and five $=$ strongly evaluated. The results of Likert 5-point measurements were also assessed on a $1=$ well below competition and $5=$ well below competitive performance(Becker, 1962; Collins \& Payne, 1991; Noble \& Mokwa, 1999; Ruekert \& Walker Jr, 1987a). While the weaknesses of perceptual actions are widely applied in management research, they are recognized (Conant et al., 1990; Huselid et al., 1997). We found that without the preliminary test answers, there was no other practical way to obtain corporate data. We are also aware that only the links between HR marketing policies and the overall performance of the enterprise are considered(Jaworski \& Kohli, 1993; McDaniel \& Kolari, 1987; O'sullivan \& Abela, 2007; Pfeffer, 1992; Slater \& Narver, 1993; Slater \& Olson, 2001; Walker Jr \& Ruekert, 1987).

\subsection{Measurement purification}

Cronbach alpha assessed the reliability of each nuclear group. There have been 0.7 ratings or higher for the 11 constructive measures. Afterwards, for rotated factor analysis, Varimax received a group response. The result was a solution with 9-factor values above 1,0, explaining 71 per cent of the 
variance. The one factor is defined by the exact correlation between the two structures as the importance of selection and education. Long-term salary is Factor Two. The third factor is defined as wage and benefits, as both constructs are closely linked. The defined Factor Four is salary and market salaries(Menon et al., 1999). An assessment is a five-man factor. The risk is defined as factor six. Factor 7 shall be defined as the consistency of internal compensation. Eight factor defines the salary of employment(J. B. Barney \& Wright, 1998; Deshpandé et al., 1993; Hrebiniak \& Joyce, 1985; Matsuno \& Mentzer, 2000).

\section{Findings and conclusions}

\subsection{Comparison of HR marketing policies by strategy type}

Table 3 shows significant differences between groups of enterprises in all 12 areas of HR policy, which comprised the four alternative business strategies (0.011 and higher). Table 3 shows, in terms of selection, training, evaluation, benefits, payments for the market, as well as long-term compensation, prospectors received the highest score, which is very similar to our forecasts. The lowest score for internal salary prospectors. The lowest margin of selection, training, estimates, salaries, benefits, market pay, risks and merits has been achieved in stark contrast, but as forecast.

For long periods, pay, and pay. Job-based pay for these companies was high as a forecast. Low-cost advocates have moderately high expectation incentives. The highest employment and internal equity levels were achieved by specific defence companies, whereas incentives were the lowest: the most incentives and the lowest employment pay. Analysts and differentiated advocates with significantly higher rates of encouragement, risk, longer-term pay and distinguished advocates with significantly higher salaries, domestic equity and pay rates usually have an intermediate gap between prospectors and defenders.

\subsection{Comparison of fit v. misfit firms within business strategy types}

Table 4 shows that 31 of 48 fitness groups were significantly different in direction, whereas six other groups did not show substantial directional differences as expected. Table 4 Shows (Table 2). For prospector enterprises 
adopting a marketing strategy (PSS), the mean choice $(0,000)$, training $(0,000)$, evaluation $(0,002)$, wages $(0,001)$, incentive $(0,000)$ and pay were considerably higher $(0.000)$. $(0,000)$. The scores in the other three types of business strategy were higher than those reported by fit companies.

Table 3. ANOVA among companies based on the business strategy adopted.

\begin{tabular}{|c|c|c|c|c|c|c|}
\hline An nraus exoepr mackism & & $\mathbf{s}$ & Mean & 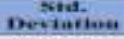 & $r$ & sig. \\
\hline Ave sulscation & FRC & 50 & 3.0 .200 & 0.80175 & & \\
\hline P. $D D=1000.0$ & ANL. & +1 & $x .47000$ & 0.49470 & & \\
\hline \multirow{3}{*}{$A=1.050 .05$} & 1,0 & 17 & 3. 18020 & o.t81 is & & \\
\hline & Dos & 47 & 3. ockeves & $0.50-460$ & & \\
\hline & Tetal & 175 & 3,4008 & 0.5 .4307 & $3.95 \times 3$ & 0,000 \\
\hline Ave. wainewh & Fero & 50 & 3,4108 & $0.5+508$ & & \\
\hline 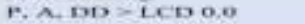 & ANL & $4 \mathrm{r}$ & 3,0000 & 0,58134 & & \\
\hline$P=-10.05$ & $1 \in D$ & $m$ & $1.88-47$ & $0,+1082$ & & \\
\hline \multirow[t]{2}{*}{ Pisoris } & nos & 47 & 3. 10004 & 0,7111 & & \\
\hline & Total & 175 & 2.94800 & 0.77496 & 38.329 & $\boldsymbol{\theta}$ \\
\hline Ave approisast & Pro & 50 & 3.4006 & 0.522 .45 & & \\
\hline r. A - R.CD 0.01: & ANE & 41 & 33201 & $0.4 \times 437$ & & \\
\hline DOS LCDOOS & $\angle C D$ & 97 & 2.9374 & $0.7898 \pi \times$ & & \\
\hline \multirow[t]{2}{*}{$r=000.05$} & Do: & 47 & 3.2310 & 0.42311 & & \\
\hline & Tetin! & 175 & 3.25000: & 0,48617 . & 6.212 & a \\
\hline Ave onlary & eres & so & $3.4 \times 37$ & $0.51+20$ & & \\
\hline$F, A, D B=L C D$ & ANI & 41 & 32775 & $0.52 n+1$ & & \\
\hline 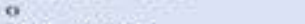 & LED & 37 & 2.718 & 0.46303 & & \\
\hline \multirow[t]{2}{*}{ Drs - A 0.05} & DE & 47 & X.sN26 & 0.57076 & & \\
\hline & Totul & 175 & 3.299 & 0.59437 & $14.49 \%$ & o \\
\hline Ave, benefit: & reno & 50 & 3.4923 & 0.40743 & & \\
\hline$E, \alpha, D D-E C D$ & ANI & +1 & 1,2200 & $0.5122 n$ & & \\
\hline 0.001 & $\mathrm{ECD}$ & -37 & 2.7312 & 0.460007 & & \\
\hline \multirow{2}{*}{$P=\wedge .0 .10$} & DES & +7 & 3.3636 & $0,4160,7$ & & \\
\hline & Teatia! & 175 & 3.2 .3 .48 & 0.57211 & 11,03 & e. \\
\hline Ave incentives: & rues & so & 3,36091 & $0,33 \times 74$ & & \\
\hline$F, A>D 000000$ & ANI. & +1 & 3,2708 & 0.45218 & & \\
\hline \multirow[t]{2}{*}{$160=000001$} & teo & 37 & 3.2048 & 0.38646 & & \\
\hline & $\mathrm{mr}$ & +7 & 3.874 .7 & $0-4.4402$ & & \\
\hline \multirow[t]{2}{*}{ Are, markert jus } & Tetial & 175 & 3.2012 & 0.40558 & 7.373 & $\mathbf{o}$ \\
\hline & ress & so & 3,0210 & $0.5 \cos 0$ & & \\
\hline D. $D D>1.000 .090$ & NNI & 4 & 2.7290 & $0.27 x 77$ & & \\
\hline$A=\operatorname{LCD} 0.1$ & $1 \mathrm{cos}$ & 37 & 2.49 .43 & 0.450001 & & \\
\hline$P=\wedge 005$ & $D D$ & 47 & 2.968 & 0.76285 & & \\
\hline$D D=10.05$ & Teria! & 175 & 2.20260 & 0.46 .708 & 2.6061 & e. \\
\hline Avor rink & SRER & 50 & 3.3724 & 0.51435 & & \\
\hline P. $A, D D=1.0 D$. & ANL & $4 \pi$ & 3.2654 & 0.50762 & & \\
\hline 0.6006 in $>13130.690$ & $1.6 D$ & 37 & 2.0 sitent & 0.1301s & & \\
\hline \multirow{2}{*}{$A>0000$} & Do & 47 & 2.8729 & 0.3831 & & \\
\hline & Total & 175 & 2.04 .33 & 0.6 .3567 & 40.0 .41 & a \\
\hline Aw. Ine -quiry & IRE & 50 & $2,7 \times 3,4$ & $0.41 .4 \times B$ & & \\
\hline$D D>10.00 i$ & ANE. & 41 & 3.0513 & 0.51022 & & \\
\hline A r poos & LD & 37 & 2.15750 & 0.51103 & & \\
\hline \multirow[t]{2}{*}{$D D>t<D 0.05$} & Dor & 47 & 3.1533 & 0.4300 .6 & & \\
\hline & Tetal & 175 & 2.9657 & 0.48110 & 3.915: & $0.0 \times 1$ \\
\hline Ave merir & FRO & so & 0.535 & 0.40257 & & \\
\hline$r=1.0130,000$ & ANL. & 41 & 3,3212 & 0.37253 & & \\
\hline$P=-$ DDos & ECD & 37 & 3,0075 & $0.2+2121$ & & \\
\hline A t-tco 0.03 & Dos & 47 & $3.2 \mathrm{kos}$ & 0.43000 & & \\
\hline $00-\operatorname{LeD} 0.05$ & Totis! & 175 & $3.38-46$ & 0.5317 & 5.0007 & 0.002 \\
\hline Ave jub-trased & men & 50 & 20230 & 0.45781 & & \\
\hline rer & ANL. & 41 & 2.10:37 & 0.41203 & & \\
\hline$L C B=P, \wedge 0.03$ & LeC & 37 & $3,283 \times$ & 0.562261 & & \\
\hline \multirow[t]{2}{*}{$D D=r . A 0.000$} & Do & 47 & 3.343 & 0.411774 & & \\
\hline & Tatuel & 175 & 3.0023 & & 7.702 & 0.ean \\
\hline Ave, lestat-term & mess & 30 & 3.4058 & $0.874 \mathrm{~ms}$ & & \\
\hline rev & ANI & 41 & 3.1704 & 0.50376 & & \\
\hline$F=\wedge .0 .01$ & LCD & 37 & $2.0 \mathrm{ke} 4$ & 0.72198 & & \\
\hline F- T.CD, DIS 0.600 & Do & 47 & $2.64-3$ & 0.53070 & & \\
\hline$A=$ LeD 6.000 & Tatal & 175 & 2.0 .452 & $0.772 k+4$ & 4.6 . & e \\
\hline$\hat{A}>00.01$ & & -1 & & & & \\
\hline $10 D-1<D 0.000$ & & -1 & & & & \\
\hline
\end{tabular}

Source: Elaborated by the author

The average score is either above 4.0 without market payor within an error of around 4.0. As a forecast, fit prospector companies, therefore, place great emphasis on commercialization and spend substantial funds on 
marketing workers rather than on the selection, training, and assessment of misfit companies. Wages, benefits and incentives are relatively high in companies that have adopted one of the other three commercial strategies, and overall compensation is more than comparable positions.

\section{Table 4. Tests of significant differences between fit and misfit firms within business strategy type}

\begin{tabular}{|c|c|c|c|c|c|c|c|c|c|c|c|c|}
\hline & \multicolumn{3}{|c|}{ Prospeders } & \multicolumn{3}{|c|}{ Anaksen } & \multicolumn{2}{|c|}{$\begin{array}{l}\text { Lon-Coid } \\
\text { Defendes }\end{array}$} & \multicolumn{4}{|c|}{ Differeatiated Defenders } \\
\hline & $\begin{array}{c}\text { Fit } \\
n=32\end{array}$ & $\begin{array}{l}\text { Mofit } \\
n=19\end{array}$ & $\begin{array}{l}\text { t/Siz } \\
\text { Dif }\end{array}$ & $\begin{array}{c}\text { Fit } \\
n=21\end{array}$ & $\begin{array}{l}\text { Misfit } \\
n-21\end{array}$ & $\begin{array}{l}\text { t/ } 5 \text { ig. } \\
\text { Dif }\end{array}$ & $\begin{array}{l}\mathrm{Fit} \\
\mathrm{x}-22\end{array}$ & $\begin{array}{l}\text { Misfit } \\
a \div 16\end{array}$ & $\begin{array}{l}\text { tSig. } \\
\text { Dif. }\end{array}$ & $\underset{a=28}{\mathrm{Fit}}$ & $\begin{array}{c}\text { Misfit } \\
\mathrm{a}-20\end{array}$ & $\begin{array}{c}\text { t/ Sig } \\
\text { Dif }\end{array}$ \\
\hline Selectios & $4.24^{-}$ & 3.14 & $6.11+$ & 414 & 338 & $500+$ & $3.77^{*}$ & 3.04 & $452+$ & 4.23 & 342 & $5.63+$ \\
\hline (SD) & $(0.576)$ & (0.598) & 0000 & (0.543) & (438) & 0.000 & $(0.453)$ & $(0543)$ & 0,000 & $(0.472)$ & $(0517)$ & 0.000 \\
\hline Training & $3,96=$ & 3.21 & $5.38+$ & 365 & 3.11 & $2.64+$ & $236^{-}$ & 1.90 & $284+$ & 3.83 & 292 & $449+$ \\
\hline (S.D) & $(0.508)$ & $(0.650)$ & 0.000 & (0.563) & $(0748)$ & 0.012 & $(0.447)$ & $(0567)$ & 0.007 & $(0.563)$ & (0878) & 0.000 \\
\hline Appraisal & $396^{\circ}$ & 3.40 & $3.21+$ & 394 & 329 & $4.05+$ & $324^{\circ}$ & 3.19 & 0.320 & 3.68 & 328 & $260+$ \\
\hline (SD) & (0.508) & $(0.624)$ & 0002 & $(0.417)$ & $(0,008)$ & 0000 & $(0.473)$ & (0.583) & 0.751 & $(0.390)$ & $(0660)$ & 0.012 \\
\hline Salary & 3.98 & 3.10 & $3.51+$ & 376 & 336 & $2.08+$ & 3.07 & 2.91 & 0,828 & $4.21^{\prime}$ & 3,38 & $500+$ \\
\hline (SD) & $(0.569)$ & $(0567)$ & 0001 & (as15) & $(0.727)$ & 0.044 & $(0583)$ & $(0.612)$ & 0.413 & $(0,499)$ & $(0.646)$ & 0.000 \\
\hline Benafits & $3.95^{\circ}$ & 3.47 & $3.00+$ & 374 & 329 & $2.43+$ & $298^{-}$ & 305 & $-0,437$ & 3,93 & 325 & $346+$ \\
\hline (S.D) & $(0.601)$ & $(0.456)$ & 0,004 & $(0.490)$ & $(0.700)$ & 0.020 & (0.523) & $(0680)$ & 0.665 & $(0.663)$ & $(0679)$ & 0.001 \\
\hline Insentives & 3.92 & 3.18 & $451+$ & 391 & 3.41 & $3.07+$ & 361 & 331 & $184+$ & $3.14^{\prime}$ & 3.18. & 0.189 \\
\hline (SD) & (0.541) & $(0.506)$ & 0000 & (0.525) & (0539) & 0.004 & $(0.510)$ & $(0.479)$ & 0.074 & (0.636) & $(0494)$ & Q.851 \\
\hline Mkt. Pay & $3.64^{-}$ & 2.74 & $5.78+$ & 3.19 & 283 & $3.15+$ & $2.93^{\circ}$ & 256 & $203+$ & 3.41 & 303 & $286+$ \\
\hline (SD) & (0.599) & $(0.421)$ & 0.000 & $(0.402)$ & $(0329)$ & 0.003 & $(0.623)$ & $(0.43)$ & 0.050 & $(0.432)$ & $(0.499)$ & 0.006 \\
\hline Rik & $3.94^{\circ}$ & 3.19 & $4.82+$ & 392 & 3.18 & $386+$ & $235^{\circ}$ & 2.40 & -0.326 & 3.20 & 3.10 & 0.682 \\
\hline (SD) & (0.532) & $(0.537)$ & 0.900 & $(0.393)$ & (0.793) & 0.000 & (0.333) & $(0.561)$ & 0.746 & $(0.5,00)$ & (0531) & 0.499 \\
\hline Int equaty & $298^{-1}$ & 321 & -149 & 338 & 329 & 0.473 & 329 & 2.98 & 1.50 & $3.61^{-}$ & 320 & $2.62+$ \\
\hline (SD.) & (0.508) & $(0580)$ & 0.142 & $\{0.669)$ & $(0.635)$ & 0.639 & $(0.410)$ & $(0.537)$ & 0.143 & $(0.481)$ & $(0596)$ & 0.012 \\
\hline Menit & $4.04^{-}$ & 3.44 & $3.78+$ & 397 & 324 & $3.94+$ & $3.64^{\prime}$ & 281 & $461+$ & 3.74 & 332 & $272+$ \\
\hline (S.D) & $(0.547)$ & $(0.556)$ & 0.000 & $(0.505)$ & $(0.684)$ & 0,000 & $(0410)$ & $(0.688)$ & 0.000 & $(0.562)$ & $(0.477)$ & 0.009 \\
\hline Iob-bssed & $306^{t}$ & 3.45 & $2.38-$ & 3.24 & 300 & 1.451 & $400^{\circ}$ & 3.03 & $5.42+$ & 3.88 & 328 & $3.78+$ \\
\hline (SD) & $(0.606)$ & $(0.468)$ & 0021 & (0.584) & $(0474)$ & 0.155 & (0533) & $(0.499)$ & 0.000 & (0.555) & $(0.525)$ & 0,000 \\
\hline Lans term & 401 & 339 & $4.33+$ & 368 & 322 & $3.30+$ & $226^{\circ}$ & 2.52 & -1.11 & 3.27 & 2.92 & $237+$ \\
\hline (S.D) & $(0.467)$ & $(0.536)$ & 0,000 & $(0.428)$ & $(0,475)$ & 0.002 & $(0.756)$ & $(0.666)$ & 0.273 & $(0.529)$ & $(0.494)$ & 0.022 \\
\hline
\end{tabular}

Source: Elaborated by the author

In comparison with its fit peers for the employment-based salary action, Fit Prospector companies also reported the only significantly low score (0.021) in all strategic types. The same companies reported a consistent lower in-house compensation, although the fitness and fitness of the prospectors did not differ statistically. We are therefore of the opinion that marketing workers at these companies are fairly risky, as their value is well measured, and the 
success or failure of their efforts cannot be apparent for a considerable time because of the long evolution of new international products.

Management promotes competition at home in such companies and rewards not so old people. The MAS (Fit) analyzer has shown significantly higher select rates (0.000), training (0.012), assessment (0.000), salary $(0.044)$ and incentive rates $(0.020)$, while the remuneration rates have been considerably higher (0.003). (0.002).

These values were considerably greater than that of the three false approaches employed by companies. Like their prospector, these companies have had a comparatively high selection, assessment, incentives, risk and benefit payments. However, they were far below fit prospectors' learning and long-term profits, whereas the internal equity compensation values were considerably higher. With seven out of twelve measures, Fit Analyzer firms were more fit for low-cost advocates, whereas Differentiated Defenders scored more than three out of twelve. We expected no significant difference in HR policies without an employment-based salary because low-cost defence companies are focussing on cost control (0.000).

In all companies following this business strategy, we have taken on the decreasing importance of marketing, as the overall importance of all but one HR marketing policy has fallen. The low costs defence firms have a high selectivity level $(0,000)$, training (0.007), incentives $(0.074)$, market wages (055) and a salary which is worthwhile compared with the three mistakes; (0.000). Nine out of 12 HR-fit marketing measures, however, had an average of less than 3.5, of which five were less than 3.0. We, therefore, understand that those values show that the relevance to low-cost advocates of this policy is moderate at best. The above mean score is merely to pay, incentives and salaries based on employment. These three policies for low-cost defence companies showed the highest overall wage and lowest merit ratings for all companies. This means that marketing staff in such enterprises mainly focus their attention on seniority and/or the extent to which they perform certain tasks instead of measures for financial results.

The incentives are, however, quite high, and the Commission's compensation is based on payment for the merits. These are risky companies. We note that both positions are incoherent. Differentiated defence firms that have adopted VAT marketing strategy (fitness), average choices (0.000), 
training (0.000), assessment (0.0012; payroll (0.001), benefit (0.001). (0.012). (0.000). Fit Differentiated Defender companies were the most important in all pay and internal compensation groups. Defenders with low costs paid only marginally less than prospectors for selection, training and benefit did.

The lowest income level is achieved by Fit Diversified Defending Companies in sharp contrast. In terms of compensation in the long term, they are significantly below fit prospectors, analyzers and significantly above lowcost advocates. These findings further support the opinion that a distinguished Defenders company's marketing services mainly focus on delivering excellent services and/or products to its existing clients in order to develop and maintain long-term relationships. These companies, therefore, highlight rapid sales and short-term incentives. This means far more play than for lowcost defender fitting companies but less for prospectors or analyzers. Table 4 shows that there were substantial differences in direction for 31 of the 48 fitness groups, while six others did not, as expected, show significant differences. The mean choice $(0,000)$, training $(0,000)$, assessment $(0,002)$, wages $(0,001)$ and incentives $(0,000)$ and wages were significantly higher for the prospector firms adopting a marketing strategy (PSS) $(0.000) .(0,000)$. The values in the other two types of business strategies were higher than the values reported by fit companies.

\subsection{Overall firm performance/equifinality}

Table 5 shows that the overall performance of the company fit strategy (0.000) is substantially greater than the inappropriate companies, thus supporting our projections.

Figure 2. Overall firm performance scores - all firms

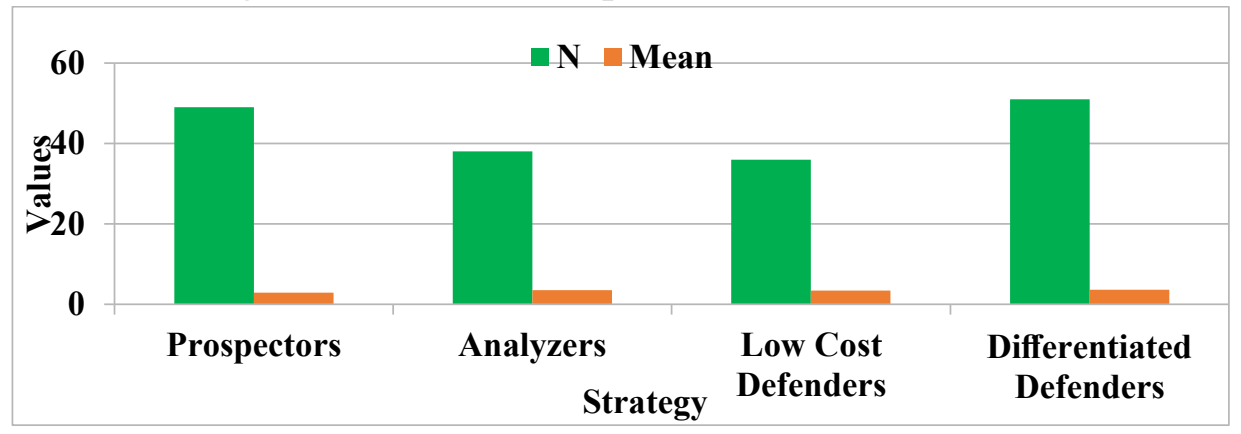

Source: Elaborated by the author 
Figure 2 indicates that the overall company performance of alternative business strategy groups does not differ substantially $(\mathrm{F}=0.881$; Sig. 0.452$)$. The overall rating for fit companies using alternative strategies $(\mathrm{F}=0.168$; sig. 0.918) showed no significant difference in Figure 3. Therefore, we believe that the data set is the same.

Figure 3. Overall firm performance scores within fit firms

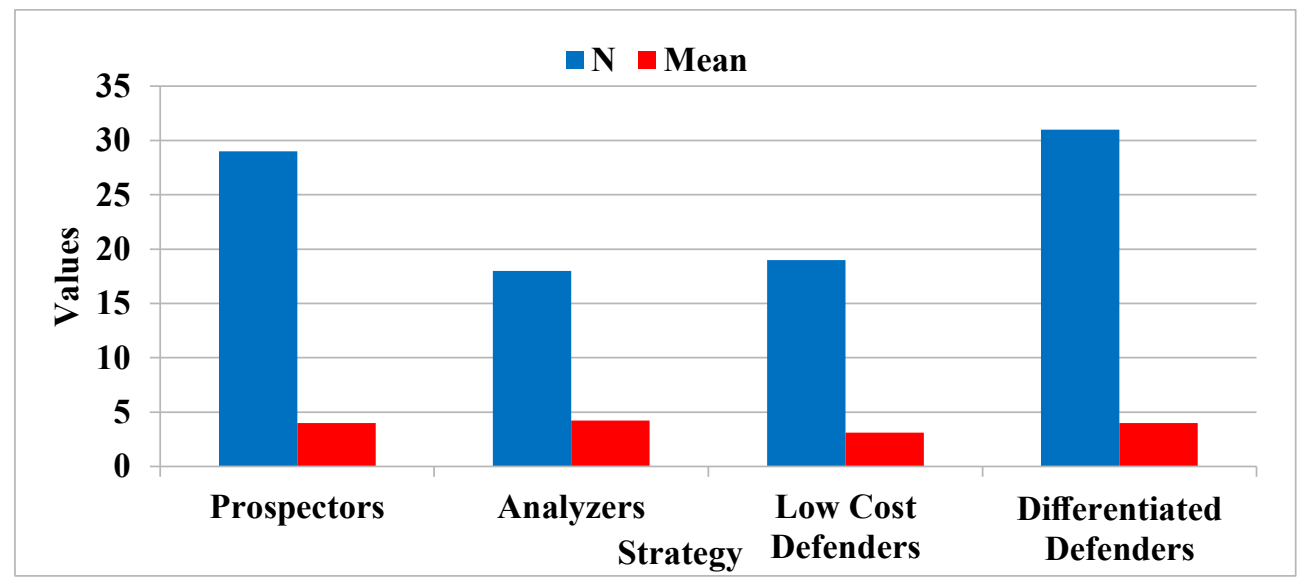

Source: Elaborated by the author

\subsection{Limitations}

Table 5 shows that the overall performance within the relevant companies of all four corporate strategies is substantially greater (0.000), which supports our prediction. Table 6 shows that in the total corporate performance rate ( $\mathrm{F}=0.881$; SIG.0.452), there are no significant differences between groups following other business strategies. Figure 3 indicates that there are no significant differences between fit companies pursuing alternative corporate strategies $(\mathrm{F}=0.168$; sig. 0.918$)$. The collection of data is therefore equivalent to our consideration. 
Table 5. Overall firm performance scores between fit and misfit firms within business strategy types.

\begin{tabular}{|c|c|c|c|c|c|c|c|c|c|c|c|c|}
\hline & \multicolumn{3}{|c|}{ Frospeders } & \multicolumn{3}{|c|}{ Auatuen } & \multicolumn{3}{|c|}{ Low-rast defeuien } & \multicolumn{3}{|c|}{$\begin{array}{l}\text { Differniliated } \\
\text { sfenden }\end{array}$} \\
\hline & Fit $a-32$ & $\begin{array}{c}\text { Misfon } \\
n \rightarrow 19\end{array}$ & USig Dir & Fif $a-21$ & Mhat $\mathrm{n}=21$ & uSie Dir & Fita-22 & Matat u-16 & UStg Dir & Fif a-28 & $\begin{array}{l}\text { Mlisen } \\
\mathrm{N}=\mathbf{2 0}\end{array}$ & tSig Dat \\
\hline $\begin{array}{l}\text { Ovenal Fim } \\
\text { Perlormasee } \\
\text { (SD) }\end{array}$ & $\begin{array}{c}4.188 \\
(0.604)\end{array}$ & $\begin{array}{l}1140 \\
(0.570)\end{array}$ & $\frac{611}{(000)}$ & $\begin{array}{l}4.127 \\
(0.532)\end{array}$ & $\begin{array}{l}3,095 \\
(0.693)\end{array}$ & $\begin{array}{l}5.415 \\
(0.000)\end{array}$ & $\begin{array}{l}4.076 \\
(0.482)\end{array}$ & $\begin{array}{l}2.75 \\
(0.735)\end{array}$ & $\begin{array}{l}6.719 \\
0.000\end{array}$ & $\begin{array}{c}4.131 \\
(0.673)\end{array}$ & $\begin{array}{l}2850 \\
(0.841)\end{array}$ & $\begin{array}{l}6.01 \\
0.00\end{array}$ \\
\hline
\end{tabular}

Source: Elaborated by the author

\section{Conclusions and recommendations for future research}

We note that compensation rates for merit and employment tend to not be mutually compensating. For instance, for one or another of these measures (Low-Cost Defender), high scores were found in a fit enterprise that was following a certain strategy; the other measures were expected to be below. However, this was not always the case. We are asking whether, for example, marketers can be evaluated primarily in the case of low-cost defence companies (i.e. employment), which primarily evaluate and offset salespersons (i.e., Merit-Based).

Despite these constraints, we believe that other researchers are concerned with the results, who studied how staff policies, business strategies and the role of marketing in carrying out corporate strategies. Therefore, by adding our findings to the marketing management and HR Managers, we can commend their processes of selecting, forming, and evaluating and compensating marketing's personnel.

\section{References}

Atuahene-Gima, K., \& Murray, J. Y. (2004). Antecedents and outcomes of marketing strategy comprehensiveness. Journal of Marketing, 68(4), 33-46.

Balkin, D. B., \& Gomez-Mejia, L. R. (1990). Matching compensation and organizational strategies. Strategic Management Journal, 11(2), 153169.

Ballantyne, D. (2000). Internal relationship marketing: a strategy for knowledge renewal. International Journal of Bank Marketing.

Barney, J. (1991). Firm resources and sustained competitive advantage. Journal of Management, 17(1), 99-120. 
Barney, J. B., \& Wright, P. M. (1998). On becoming a strategic partner: The role of human resources in gaining competitive advantage. Human Resource Management: Published in Cooperation with the School of Business Administration, The University of Michigan and in Alliance with the Society of Human Resources Management, 37(1), 31-46.

Becker, G. S. (1962). Investment in human capital: A theoretical analysis. Journal of Political Economy, 70(5, Part 2), 9-49.

Bund, H., \& Carroll, J. W. (1957). The changing role of the marketing function. Journal of Marketing, 21(3), 268-325.

Child, J. (1972). Organizational structure, environment and performance: The role of strategic choice. Sociology, 6(1), 1-22.

Chimhanzi, J. (2004). The impact of marketing/HR interactions on marketing strategy implementation. European Journal of Marketing.

Collins, B., \& Payne, A. (1991). Internal marketing: a new perspective for HRM. European Management Journal, 9(3), 261-270.

Conant, J. S., Mokwa, M. P., \& Varadarajan, P. R. (1990). Strategic types, distinctive marketing competencies and organizational performance: a multiple measures-based studies. Strategic Management Journal, 11(5), 365-383.

Corey, R. (1992). Marketing strategy: an overview. Harvard Business Review.

Cravens, D. W. (1998). Implementation strategies in the market-driven strategy era. Journal of the Academy of Marketing Science, 26(3), 237241.

Deshpandé, R., Farley, J. U., \& Webster Jr, F. E. (1993). Corporate culture, customer orientation, and innovativeness in Japanese firms: a quadrant analysis. Journal of Marketing, 57(1), 23-37.

Giannakis, D., \& Harker, M. J. (2014). Strategic alignment between relationship marketing and human resource management in financial services organizations. Journal of Strategic Marketing, 22(5), 396-419.

Gresov, C., \& Drazin, R. (1997). Equifinality: Functional equivalence in organization design. Academy of Management Review, 22(2), 403-428.

Hambrick, D. C. (2003). On the staying power of defenders, analyzers, and prospectors. Academy of Management Perspectives, 17(4), 115-118.

Hofstede, G. (1978). The poverty of management control philosophy. Academy of Management Review, 3(3), 450-461.

Homburg, C., Artz, M., \& Wieseke, J. (2012). Marketing performance measurement systems: does comprehensiveness really improve performance? Journal of Marketing, 76(3), 56-77.

Hrebiniak, L. G., \& Joyce, W. F. (1985). Organizational adaptation: Strategic choice and environmental determinism. Administrative Science 
Quarterly, 336-349.

Huber, G. P., \& Power, D. J. (1985). Retrospective reports of strategic-level managers: Guidelines for increasing their accuracy. Strategic Management Journal, 6(2), 171-180.

Hunt, S. D., \& Morgan, R. M. (1995). The comparative advantage theory of competition. Journal of Marketing, 59(2), 1-15.

Huselid, M. A., Jackson, S. E., \& Schuler, R. S. (1997). Technical and strategic human resources management effectiveness as determinants of firm performance. Academy of Management Journal, 40(1), 171-188.

Ittner, C. D., \& Larcker, D. F. (1997). Product development cycle time and organizational performance. Journal of Marketing Research, 34(1), 1323.

James, W. L., \& Hatten, K. J. (1995). Further evidence on the validity of the self typing paragraph approach: Miles and Snow strategic archetypes in banking. Strategic Management Journal, 16(2), 161-168.

Jaworski, B. J., \& Kohli, A. K. (1993). Market orientation: antecedents and consequences. Journal of Marketing, 57(3), 53-70.

Katz, D., \& Kahn, R. L. (1978). The social psychology of organizations (Vol. 2). Wiley New York.

Kotler, P., \& Turner, R. E. (1997). Marketing management: Analysis, planning, implementation, and control (Vol. 9). Prentice hall Upper Saddle River, NJ.

Matsuno, K., \& Mentzer, J. T. (2000). The effects of strategy type on the market orientation-performance relationship. Journal of Marketing, 64(4), 1-16.

McCarthy, E. J., Shapiro, S. J., \& Perreault, W. D. (1979). Basic marketing. Irwin-Dorsey Ontario.

McDaniel, S. W., \& Kolari, J. W. (1987). Marketing strategy implications of the Miles and Snow strategic typology. Journal of Marketing, 51(4), 1930.

McKee, D. O., Varadarajan, P. R., \& Pride, W. M. (1989). Strategic adaptability and firm performance: a market-contingent perspective. Journal of Marketing, 53(3), 21-35.

Menon, A., Bharadwaj, S. G., Adidam, P. T., \& Edison, S. W. (1999). Antecedents and consequences of marketing strategy making: a model and a test. Journal of Marketing, 63(2), 18-40.

Miles, R. E., Snow, C. C., Meyer, A. D., \& Coleman Jr, H. J. (1978). Organizational strategy, structure, and process. Academy of Management Review, 3(3), 546-562.

Morgan, N. A., Kaleka, A., \& Katsikeas, C. S. (2004). Antecedents of export venture performance: A theoretical model and empirical assessment. 
Journal of Marketing, 68(1), 90-108.

Noble, C. H., \& Mokwa, M. P. (1999). Implementing marketing strategies: Developing and testing a managerial theory. Journal of Marketing, 63(4), 57-73.

O'sullivan, D., \& Abela, A. V. (2007). Marketing performance measurement ability and firm performance. Journal of Marketing, 71(2), 79-93.

Olson, E. M. (1994). Interdependence, Conflict, and Conflict Resolution: Design's Relationships with R \& D, Marketing, and Manufacturing. Design Management Journal (Former Series), 5(4), 60-66.

Olson, E. M., \& Slater, S. F. (2002). The balanced scorecard, competitive strategy, and performance. Business Horizons, 45(3), 11-16.

Olson, E. M., Slater, S. F., \& Hult, G. T. M. (2005). The importance of structure and process to strategy implementation. Business Horizons, 48(1), 47-54.

Olson, E. M., Walker Jr, O. C., Ruekerf, R. W., \& Bonnerd, J. M. (2001). Patterns of cooperation during new product development among marketing, operations and R\&D: Implications for project performance. Journal of Product Innovation Management: An International Publication of The Product Development \& Management Association, 18(4), 258-271.

Olson, E. M., Walker Jr, O. C., \& Ruekert, R. W. (1995). Organizing for effective new product development: The moderating role of product innovativeness. Journal of Marketing, 59(1), 48-62.

Pfeffer, J. (1992). Managing with power: Politics and influence in organizations. Harvard Business Press.

Pfeffer, J., \& Salancik, G. R. (2003). The external control of organizations: A resource dependence perspective. Stanford University Press.

Piercy, N. F. (1998). Marketing implementation: the implications of marketing paradigm weakness for the strategy execution process. Journal of the Academy of Marketing Science, 26(3), 222-236.

Porter, M. E. (1980). Competitive Strategy: Techniques for Analyzing Industries and Competitors New York: The Free Press, Harvard Business Publishing, USA.

Rafiq, M., \& Ahmed, P. K. (1993). The scope of internal marketing: defining the boundary between marketing and human resource management. Journal of Marketing Management, 9(3), 219-232.

Ruekert, R. W., \& Walker Jr, O. C. (1987a). Interactions between marketing and R\&D departments in implementing different business strategies. Strategic Management Journal, 8(3), 233-248.

Ruekert, R. W., \& Walker Jr, O. C. (1987b). Marketing's interaction with other functional units: A conceptual framework and empirical evidence. 
Journal of Marketing, 51(1), 1-19.

Schuler, R. S., \& MacMillan, I. C. (1984). Gaining competitive advantage through human resource management practices. Human Resource Management, 23(3), 241-255.

Shortell, S. M., \& Zajac, E. J. (1990). Perceptual and archival measures of Miles and Snow's strategic types: A comprehensive assessment of reliability and validity. Academy of Management Journal, 33(4), 817832.

Slater, S. F., Hult, G. T. M., \& desh, E. M. (2007). On the importance of matching strategic behaviour and target market selection to business strategy in high-tech markets. Journal of the Academy of Marketing Science, 35(1), 5-17.

Slater, S. F., \& Narver, J. C. (1993). Product-market strategy and performance: an analysis of the Miles and Snow strategy types. European Journal of Marketing, 27(10), 33-51.

Slater, S. F., \& Olson, E. M. (2000). Strategy type and performance: the influence of sales force management. Strategic Management Journal, $21(8), 813-829$.

Slater, S. F., \& Olson, E. M. (2001). Marketing's contribution to the implementation of business strategy: An empirical analysis. Strategic Management Journal, 22(11), 1055-1067.

Slater, S. F., \& Olson, E. M. (2002). A fresh look at industry and market analysis. Business Horizons, 45(1), 15-22.

Slater, S. F., Olson, E. M., \& Finnegan, C. (2011). Business strategy, marketing organization culture, and performance. Marketing Letters, 22(3), 227-242.

Slater, S. F., Olson, E. M., \& Hult, G. T. M. (2006). The moderating influence of strategic orientation on the strategy formation capability-performance relationship. Strategic Management Journal, 27(12), 1221-1231.

Snell, S. A., \& Dean Jr, J. W. (1992). Integrated manufacturing and human resource management: A human capital perspective. Academy of Management Journal, 35(3), 467-504.

Varadarajan, P. R., \& Clark, T. (1994). Delineating the scope of corporate, business, and marketing strategy. Journal of Business Research, 31(23), 93-105.

Venkatraman, N. (1990). Performance implications of strategic coalignment: a methodological perspective. Journal of Management Studies, 27(1), $19-41$.

Vorhies, D. W., \& Morgan, N. A. (2003). A configuration theory assessment of marketing organization fit with business strategy and its relationship with marketing performance. Journal of Marketing, 67(1), 100-115. 
Vorhies, D. W., \& Morgan, N. A. (2005). Benchmarking marketing capabilities for sustainable competitive advantage. Journal of Marketing, 69(1), 80-94.

Walker Jr, O. C., \& Ruekert, R. W. (1987). Marketing's role in the implementation of business strategies: a critical review and conceptual framework. Journal of Marketing, 51(3), 15-33.

Workman Jr, J. P., Homburg, C., \& Gruner, K. (1998). Marketing organization: An integrative framework of dimensions and determinants. Journal of Marketing, 62(3), 21-41.

Wright, P. M., Dunford, B. B., \& Snell, S. A. (2001). Human resources and the resource-based view of the firm. Journal of Management, 27(6), 701-721.

Wright, P. M., McMahan, G. C., \& McWilliams, A. (1994). Human resources and sustained competitive advantage: a resource-based perspective. International Journal of Human Resource Management, 5(2), 301-326.

Yarbrough, L., Morgan, N. A., \& Vorhies, D. W. (2011). The impact of product market strategy-organizational culture fit on business performance. Journal of the Academy of Marketing Science, 39(4), 555573. 